\title{
Caminibacter mediatlanticus sp. nov., a thermophilic, chemolithoautotrophic, nitrate-ammonifying bacterium isolated from a deep-sea hydrothermal vent on the Mid-Atlantic Ridge
}

\author{
James W. Voordeckers, ${ }^{1,2}$ Valentin Starovoytov ${ }^{3}$ and Costantino Vetriani ${ }^{1,2}$ \\ 1,2Department of Biochemistry and Microbiology ${ }^{1}$ and Institute of Marine and Coastal \\ Sciences ${ }^{2}$, Rutgers University, New Brunswick, NJ 08901, USA \\ ${ }^{3}$ Department of Cell Biology and Neuroscience, Rutgers University, Piscataway, NJ 08854, USA
}

Correspondence
Costantino Vetriani
vetriani@imcs.rutgers.edu
Until very recently, the class 'Epsilonproteobacteria' was thought to comprise a single order, the 'Campylobacterales', and two families, the Campylobacteraceae and the 'Helicobacteraceae' (Kersters et al., 2003). These two families include the genera Arcobacter, Campylobacter, Sulfurospirillum, Thiomicrospira, Thiovolum, Helicobacter and Wolinella. The organisms that belong to these genera are mesophilic, microaerobic or anaerobic bacteria, which are found in aquatic environments or in association with animals. However, the recent characterization of a number of novel $\varepsilon$-proteobacteria has revealed that the taxonomy of this class is more complex than previously recognized (Campbell et al., 2001; Alain et al., 2002b; Miroshnichenko et al., 2002, 2004; Takai et al., 2003). A new order, the Nautiliales, was recently proposed to include two genera,

Published online ahead of print on 18 October 2004 as DOI 10.1099/ ijs.0.63430-0.

The GenBank/EMBL/DDBJ accession number for the 16S rRNA gene sequence of strain TB-2 ${ }^{\top}$ is AY691430.
Caminibacter and Nautilia, both of which comprise thermophilic bacteria isolated from deep-sea hydrothermal vents (Miroshnichenko et al., 2004). Nautilia lithotrophica, a thermophilic, anaerobic, sulfur-reducing bacterium, was isolated from tubes of the vent polychaete Alvinella pompejana, and is the only representative of this genus (Miroshnichenko et al., 2002). Caminibacter hydrogeniphilus and Caminibacter profundus are both thermophilic, sulfur- and nitrate-reducing bacteria that were isolated from deep-sea hydrothermal vents (Alain et al., 2002b; Miroshnichenko et al., 2004). In addition to exhibiting anaerobic growth, Caminibacter profundus is also able to grow microaerobically. Caminibacter hydrogeniphilus was isolated from Alvinella pompejana tubes, while Caminibacter profundus was isolated from biomass collected using an environmental growth chamber. Furthermore, four new genera within the 'Epsilonproteobacteria' were described recently: Sulfurimonas, Sulfurovum, Sulfuricurvum and Hydrogenimonas. Sulfurimonas autotrophica, Sulfurovum lithotrophicum and Sulfuricurvum kujiense are mesophilic, facultatively microaerobic, sulfur- and thiosulfate-oxidizing 
bacteria (Kodama \& Watanabe, 2004; Inagaki et al., 2003, 2004). While Sulfurimonas autotrophica and Sulfurovum lithotrophicum were isolated from deep-sea hydrothermal sediments, Sulfuricurvum kujiense was isolated from an underwater crude-oil storage cavity. Hydrogenimonas thermophila is a thermophilic, facultatively microaerobic, hydrogen-oxidizing bacterium isolated from a deep-sea hydrothermal vent on the Central Indian Ridge (Takai et al., 2004). Overall, the discovery of these novel organisms revealed a broad taxonomic diversity within the 'Epsilonproteobacteria', and indicates that a revision of the classification of these organisms is timely.

Culture-independent analyses of microbial communities associated with sulfide structures and vent invertebrates have indicated that $\varepsilon$-proteobacteria are widely distributed at deep-sea hydrothermal vents throughout the world's oceans (Haddad et al., 1995; Polz \& Cavanaugh, 1995; Cary et al., 1997; Reysenbach et al., 2000; Campbell et al., 2001; Corre et al., 2001; Longnecker \& Reysenbach, 2001; Alain et al., 2002a; Hoek et al., 2003; Huber et al., 2003). Furthermore, experiments in which various types of colonization substrates were deployed in the vicinity of active deep-sea vents revealed that between 66 and $98 \%$ of the micro-organisms associated with these substrates belonged to the 'Epsilonproteobacteria' (López-García et al., 2003; Takai et al., 2003; Alain et al., 2004). Overall, these observations suggest that $\varepsilon$-proteobacteria represent a dominant fraction of the microbial communities at deep-sea hydrothermal vents. Here, we describe the isolation and characterization of a novel thermophilic, chemolithoautotrophic, strictly anaerobic, nitrate-ammonifying $\varepsilon$-proteobacterium that was isolated from a deep-sea hydrothermal vent on the Mid-Atlantic Ridge.

Fragments of active, high-temperature, black smoker chimneys were collected from the 'Rainbow' vent field on the Mid-Atlantic Ridge ( $\left.36^{\circ} 14^{\prime} \mathrm{N} 33^{\circ} 54^{\prime} \mathrm{W}\right)$ at a depth of $2305 \mathrm{~m}$ during a cruise aboard $\mathrm{R} / \mathrm{V}$ Atlantis (cruise AT 05-03, July 2001). The samples were collected using the manipulator of the DSV Alvin and stored in boxes on the submersible's working platform for the rest of the dive. On the surface, samples were transferred to the ship's laboratory and subsamples were stored at $4{ }^{\circ} \mathrm{C}$ under a dinitrogen atmosphere until use in the laboratory. Primary enrichment cultures were initiated by adding about $1 \mathrm{ml}$ inoculum (prepared by resuspending approximately $1 \mathrm{~g}$ chimney sample in $1 \mathrm{ml}$ anaerobic artificial sea water) to $10 \mathrm{ml}$ modified SME medium that had been prepared as previously described (Stetter et al., 1983; Vetriani et al., 2004). Artificial sea water is composed of the following salts $\left(1^{-1}\right): \mathrm{NaCl}(28 \cdot 13 \mathrm{~g}), \mathrm{KCl}(0 \cdot 77 \mathrm{~g}), \mathrm{CaCl}_{2} \cdot 2 \mathrm{H}_{2} \mathrm{O}$, $(1.60 \mathrm{~g}), \mathrm{MgCl}_{2} \cdot 6 \mathrm{H}_{2} \mathrm{O}(4 \cdot 80 \mathrm{~g}), \mathrm{NaHCO}_{3}(0 \cdot 11 \mathrm{~g})$ and $\mathrm{MgSO}_{4} \cdot 7 \mathrm{H}_{2} \mathrm{O}(3 \cdot 50 \mathrm{~g})$. For the isolation of single colonies, plates containing modified SME medium solidified with $1 \mathrm{~g}$ Phytagel (Sigma) $\mathrm{l}^{-1}$ were used. Plates were incubated in an anaerobic jar (Oxoid) pressurized with $\mathrm{H}_{2} / \mathrm{CO}_{2}$ $(80: 20 ; 70 \mathrm{kPa})$. Long-term stocks were prepared by adding $50 \mu \mathrm{l}$ DSMO (Fisher Scientific) to $1 \mathrm{ml}$ culture; storage was at $-80{ }^{\circ} \mathrm{C}$.

Growth rates $\left(\mu ; \mathrm{h}^{-1}\right)$ were estimated as $\mu=\left(\ln \mathrm{N}_{2}-\ln \mathrm{N}_{1}\right)$ / $\left(t_{2}-t_{1}\right)$, where $\mathrm{N}_{2}$ and $\mathrm{N}_{1}$ are numbers of cells $\mathrm{ml}^{-1}$ at times (in h) $t_{2}$ and $t_{1}$. Generation times $\left(t_{\mathrm{g}} ; \mathrm{h}\right)$ were calculated as $t_{\mathrm{g}}=(\ln 2) / \mu$. All growth experiments were carried out in duplicate. The optimal growth temperature for strain TB- $2^{\mathrm{T}}$ was determined by incubating cultures at temperatures between 40 and $80^{\circ} \mathrm{C}$ (at $5^{\circ} \mathrm{C}$ intervals). All other experiments were carried out at $55^{\circ} \mathrm{C}$. The optimal salt requirement was determined by varying the concentration of $\mathrm{NaCl}$ between 10 and $45 \mathrm{~g} \mathrm{l}^{-1}$, at $5 \mathrm{~g} \mathrm{l}^{-1}$ intervals. The optimal $\mathrm{pH}$ for growth was determined by varying the $\mathrm{pH}$ in the culture medium between $4 \cdot 0$ and $8 \cdot 5$, using the following buffers at a concentration of $10 \mathrm{mM}$ : acetate at $\mathrm{pH} 4 \cdot 0,4 \cdot 5$ and $5 \cdot 0$, MES at $\mathrm{pH} 5.5$ and $6 \cdot 0$, PIPES at $\mathrm{pH} 6.5$ and $7 \cdot 0$, HEPES at $\mathrm{pH} 7 \cdot 5$ and Tris at $\mathrm{pH} 8 \cdot 0$ and $8 \cdot 5$. Antibiotic resistance was tested in the presence of ampicillin, chloramphenicol, kanamycin and streptomycin (all $100 \mu \mathrm{g} \mathrm{ml}^{-1}$ ). All antibiotics were added aseptically before incubation at $55^{\circ} \mathrm{C}$ and an ethanol control was performed for chloramphenicol. The effect of organic substrates upon the growth of strain TB- $2^{\mathrm{T}}$ was investigated by adding the following substrates to the medium under a $\mathrm{H}_{2} /$ $\mathrm{CO}_{2}$ gas phase $(80: 20 ; 200 \mathrm{kPa})$ : acetate, formate, lactate, peptone, tryptone, Casamino acids, $\mathrm{D}(+)$-glucose, sucrose (all at $\left.2 \mathrm{~g} \mathrm{l}^{-1}\right)$ and yeast extract $\left(0 \cdot 1\right.$ and $\left.1 \mathrm{~g} \mathrm{l}^{-1}\right)$. These substrates were also tested as possible energy and/or carbon sources by using the following gas phases: $\mathrm{N}_{2} / \mathrm{CO}_{2}(80: 20$; $200 \mathrm{kPa}), \mathrm{N}_{2}(100 \% ; 200 \mathrm{kPa})$ or $\mathrm{H}_{2}(100 \% ; 200 \mathrm{kPa})$. The ability of TB- $2^{\mathrm{T}}$ to use alternative electron acceptors was tested by adding thiosulfate $(0 \cdot 1 \%$, w/v), sulfite $(0 \cdot 1 \%$, $\mathrm{w} / \mathrm{v})$, arsenate $(5 \mathrm{mM})$, selenate $(5 \mathrm{mM})$, sulfur $(3 \%, \mathrm{w} / \mathrm{v})$ and oxygen $(0.5 \%, \mathrm{v} / \mathrm{v})$ to nitrate-depleted media.

Quantitative determinations of nitrate, nitrite and ammonium were carried out spectrophotometrically using a Lachat QuikChem automated ion analyser according to the manufacturer's specifications (Diamond, 1993a, b). Qualitative determination of hydrogen sulfide was carried out as previously described (Vetriani et al., 2004). For the determination of catalase, cells were collected by centrifugation from $1.5 \mathrm{ml}$ overnight culture resuspended in $70 \mu \mathrm{l}$ $3 \%$ solution of $\mathrm{H}_{2} \mathrm{O}_{2}$ and then incubated both at $55^{\circ} \mathrm{C}$ and at room temperature. A cell-free $3 \%$ solution of $\mathrm{H}_{2} \mathrm{O}_{2}$ was used as a negative control. The presence of catalase was detected from the formation of gas bubbles.

Cells were routinely stained in $0 \cdot 1 \%$ acridine orange and visualized with an Olympus BX 60 microscope with an oil immersion objective (UPlanF1 100/1·3). For ultrathin sections, cells were fixed for $3 \mathrm{~h}$ in Karnovsky's fixative [formaldehyde, $4 \%(\mathrm{v} / \mathrm{v})$ and glutaraldehyde, $1 \%(\mathrm{v} / \mathrm{v})$ in $0 \cdot 1 \mathrm{M}$ Millonig's phosphate buffer, $\mathrm{pH} 7 \cdot 3$ ) and then incubated in $1 \%$ osmium tetroxide for $1 \mathrm{~h}$ and dehydrated in a graded ethanol series. Cells were then embedded in Epon-Araldite (Electron Microscopy Sciences) and sectioned with a diamond knife (LKB 2088 ultramicrotome; 
LKB Produkter). Thin sections were stained with a $5 \%$ $(\mathrm{w} / \mathrm{v})$ uranyl acetate solution in $50 \%$ ethanol for $15 \mathrm{~min}$ and then with a $0.5 \%(\mathrm{w} / \mathrm{v})$ lead citrate solution in $\mathrm{CO}_{2}$ free, double-distilled water for $2 \mathrm{~min}$. For direct visualization, cells were fixed and applied to a copper Formvar (Electron Microscopy Sciences)/carbon-coated grid. The grids were air-dried and shadowed with $2 \mathrm{~nm} \mathrm{Pt} / \mathrm{C}$ (angle, $15^{\circ}$ ) by using a high-vacuum freeze-etch unit (BAF 300; Balzers). Electron micrographs were taken using a model JEM 100 CX transmission electron microscope (JEOL).

Genomic DNA was extracted from cells of strain TB- $2^{\mathrm{T}}$ by using the UltraClean microbial DNA isolation kit (MoBio). The 16S rRNA gene was selectively amplified from the genomic DNA by PCR as described previously (Vetriani et al., 1999, 2004) and its sequence was determined for both strands on an ABI 3100-Avant genetic analyser (Applied Biosystems). Sequences were aligned automatically using CLUSTAL $\mathrm{X}$ and the alignment was manually refined using SEAVIEW (Galtier et al., 1996; Thompson et al., 1997). Neighbour-joining trees were constructed by using the least-squares algorithm of De Soete from a normal evolutionary distance matrix, using Phylo_Win (De Soete, 1983; Perrière \& Gouy, 1996). Approximately 1204 homologous nucleotides were included in the analysis, and 500 bootstrap replicates were carried out to provide confidence estimates for phylogenetic tree topologies. The DNA G $+\mathrm{C}$ content of TB- $2^{\mathrm{T}}$ and the DNA-DNA hybridization between Caminibacter profundus and $\mathrm{TB}-2^{\mathrm{T}}$ were determined as previously described (Vetriani et al., 2004).

Enrichment cultures for thermophilic, chemolithotrophic organisms were obtained by inoculating $10 \mathrm{ml}$ modified SME medium (supplemented with $10 \%(\mathrm{w} / \mathrm{v})$ nitrate or $3 \%(\mathrm{w} / \mathrm{v})$ elemental sulfur) with $1 \mathrm{ml}$ slurries from a hightemperature vent $\left(158^{\circ} \mathrm{C}\right)$ located on the Mid-Atlantic Ridge. Cultures were incubated at 50,65 and $80^{\circ} \mathrm{C}$. Turbidity was observed within 2 days and $0.1 \mathrm{ml}$ aliquots of the original cultures were subsequently transferred to fresh medium. Two independent cultures, supplemented with nitrate as the terminal electron acceptor, showed consistent growth after repeated transfers at 50 and $65^{\circ} \mathrm{C}$, respectively. Pure cultures were obtained by isolating single colonies on solidified medium. Both cultures comprised short rods and were designated strain TB-1 $\left(50^{\circ} \mathrm{C}\right)$ and strain $\mathrm{TB}-2^{\mathrm{T}}\left(65^{\circ} \mathrm{C}\right)$. Preliminary phylogenetic analysis of the 16S rRNA gene sequences indicated that strains TB- 1 and TB- $2^{\mathrm{T}}$ were closely related (sequence identity: $99 \%)$ TB- $2^{\mathrm{T}}$ was chosen for further characterization. TB- $2^{\mathrm{T}}$ cells were short rods, approximately $1 \cdot 5-2 \cdot 0 \mu \mathrm{m}$ in length and $0.75 \mu \mathrm{m}$ in width, that stained Gram-negative (Fig. 1a). The cell envelope of TB- $2^{\mathrm{T}}$ included a cytoplasmic

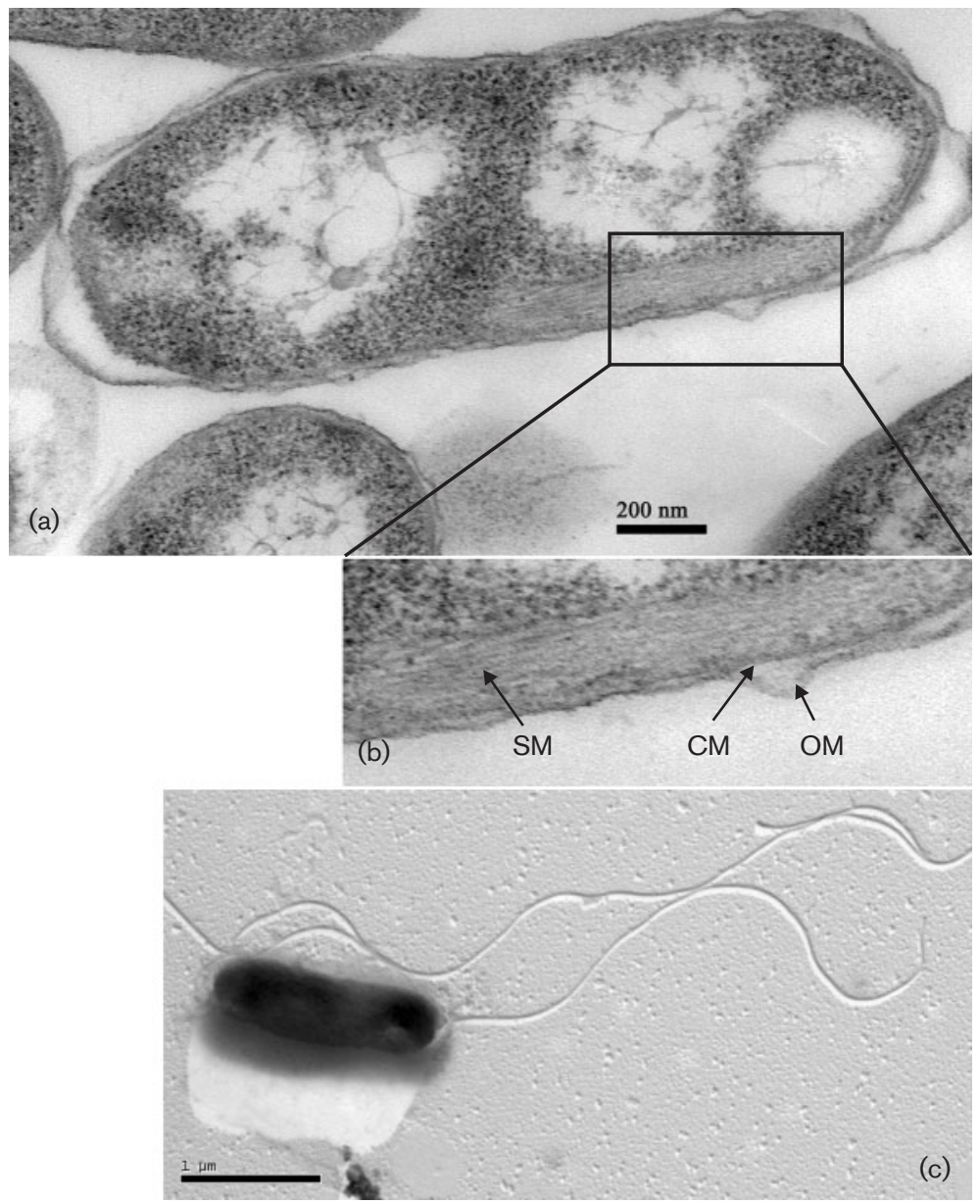

Fig. 1. (a) Electron micrograph of a thin section of cells of strain TB-2 ${ }^{\top}$, showing cell morphology and stacked membrane feature. (b) Ultrastructural details of stacked membranes and cell envelope of strain $\mathrm{TB}-2^{\top}$. $\mathrm{SM}$, Stacked membrane; CM, cytoplasmic membrane; OM, outer membrane. (c) Electron micrograph of platinum-shadowed $\mathrm{TB}^{\top}$ cell, showing multiple polar flagella. Bars, $200 \mathrm{~nm}$ (a), $1 \mu \mathrm{m}$ (c). 
membrane surrounded by the periplasmic space and an outer membrane (Fig. 1b). Ultrathin sections revealed the presence of stacked membranes (Fig. 1b). TB- $2^{\mathrm{T}}$ possessed one or more polar flagella, as observed in platinumshadowed electron micrographs (Fig. 1c). The presence of spores was never observed and the cells divided by constriction.

Strain TB-2 $2^{\mathrm{T}}$ grew at temperatures between 45 and $70^{\circ} \mathrm{C}$, with optimal growth at $55^{\circ} \mathrm{C}$ (optimal growth for TB- 1 was at $50{ }^{\circ} \mathrm{C}$ ). No growth was detected at 40 or $75^{\circ} \mathrm{C}$. TB- $2^{\mathrm{T}}$ grew at $\mathrm{NaCl}$ concentrations between 10 and $40 \mathrm{~g} \mathrm{l}^{-1}$, with optimal growth at $30 \mathrm{~g} \mathrm{l}^{-1}$ (no growth was detected at $\left.45 \mathrm{~g} \mathrm{l}^{-1}\right)$. Growth of strain $\mathrm{TB}-2^{\mathrm{T}}$ occurred between $\mathrm{pH} 4 \cdot 5$ and $\mathrm{pH} 7 \cdot 5$, with an optimum at $\mathrm{pH} 5 \cdot 5$. Under optimal conditions, the generation time of isolate TB- $2^{\mathrm{T}}$ was $50 \mathrm{~min} . \mathrm{TB}-2^{\mathrm{T}}$ is a strictly anaerobic, chemolithoautotrophic bacterium that used nitrate, $\mathrm{H}_{2}$ and carbon dioxide as the primary electron acceptor, electron donor and carbon source, respectively. Under these conditions, nitrate was reduced to ammonium in stoichiometric amounts, and nitrite did not accumulate in the culture medium (Fig. 2). Growth of $\mathrm{TB}-2^{\mathrm{T}}$ was also supported by elemental sulfur as the terminal electron acceptor, with concomitant production of $\mathrm{H}_{2} \mathrm{~S}$. Under these conditions, TB- $2^{\mathrm{T}}$ underwent a lag phase of about $12 \mathrm{~h}$, and the generation time was $7 \cdot 0 \mathrm{~h}$. Strain TB- $2^{\mathrm{T}}$ did not grow when oxygen $(0.5 \%, \mathrm{v} / \mathrm{v})$, arsenate $(5 \mathrm{mM})$, selenate $(5 \mathrm{mM})$, thiosulfate $(0 \cdot 1 \%$, w/v $)$ or sulfite $(0 \cdot 1 \% \mathrm{w} / \mathrm{v})$ were used as electron acceptors. In nitrate-containing medium, the presence of oxygen $(0.5 \%$, v/v) inhibited growth. In contrast, Caminibacter profundus grew in medium with $\mathrm{H}_{2} / \mathrm{CO}_{2} / \mathrm{O}_{2} \quad(79 \cdot 75: 19 \cdot 75: 0 \cdot 5$; $200 \mathrm{kPa}$ ) as the gas phase.

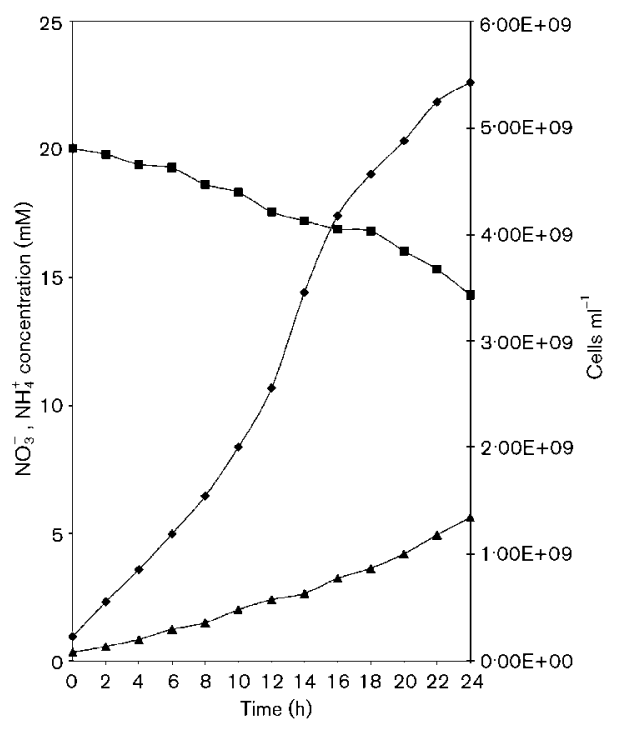

Fig. 2. Nitrate consumption and ammonium formation during growth of strain $\mathrm{TB}^{\mathrm{T}} \mathrm{2}^{\top}$. $\boldsymbol{\Delta}$, ammonium production.
Growth of TB- $2^{\mathrm{T}}$ was inhibited by the presence of acetate, formate, lactate and peptone (all at $2 \mathrm{~g} \mathrm{l}^{-1}$ ) under a $\mathrm{H}_{2} / \mathrm{CO}_{2}$ gas phase. No inhibition was observed under a $\mathrm{H}_{2} / \mathrm{CO}_{2}$ $(80: 20 ; 200 \mathrm{kPa})$ gas phase in the presence of tryptone, Casamino acids, sucrose, glucose (all at $2 \mathrm{~g} \mathrm{l}^{-1}$ ) and yeast extract $\left(0 \cdot 1\right.$ and $\left.1 \mathrm{~g} \mathrm{l}^{-1}\right)$. However, no growth was observed with these substrates under a $\mathrm{N}_{2} / \mathrm{CO}_{2}$ or $\mathrm{H}_{2}$ gas phase. Strain $\mathrm{TB}-2^{\mathrm{T}}$ was inhibited by chloramphenicol, ampicillin and streptomycin, but not by kanamycin. Strain TB-2 ${ }^{\mathrm{T}}$ exhibited weak catalase activity after concentrated cells were incubated in the presence of $\mathrm{H}_{2} \mathrm{O}_{2}$, both at $55^{\circ} \mathrm{C}$ and at room temperature.

The genomic DNA G + C content of strain TB- $2^{\mathrm{T}}$, determined by HPLC analysis of the deoxyribonucleosides, was $25.6 \mathrm{~mol} \%$. DNA-DNA hybridization experiments with Caminibacter profundus revealed a relatedness of $35.7 \%$ between the organisms. Phylogenetic analysis of the $16 \mathrm{~S}$ rRNA gene sequences, carried out using the neighbourjoining method, placed both TB-2 ${ }^{\mathrm{T}}$ and TB-1 within the class 'Epsilonproteobacteria' (Fig. 3). Both of these strains, whose sequences were $99 \%$ similar, were placed in a discrete cluster in the genus Caminibacter (Fig. 3). The next closest relatives to both TB-1 and TB- $2^{\mathrm{T}}$ were Caminibacter hydrogeniphilus and Caminibacter profundus (95.9 and $96 \cdot 3 \%$ sequence similarity, respectively), which branched in separate clusters (Fig. 3). High bootstrap values supported the branching topology of the four Caminibacter strains (Fig. 3).

Strain TB- $2^{\mathrm{T}}$ could be assigned to the genus Caminibacter, although this organism could be differentiated from the previously described Caminibacter species by means of several physiological characteristics (Table 1). The $\mathrm{G}+\mathrm{C}$ content of the DNA of TB- $2^{\mathrm{T}}(25 \cdot 6 \mathrm{~mol} \%)$ was lower than that of either Caminibacter hydrogeniphilus $(29 \pm 1 \mathrm{~mol} \%)$ or Caminibacter profundus $(32 \cdot 1 \mathrm{~mol} \%$ ) (Alain et al., 2002b; Miroshnichenko et al., 2004). TB- $2^{\mathrm{T}}$ could be distinguished from Caminibacter hydrogeniphilus by a lower optimum growth temperature, a higher optimum salinity and a shorter generation time; it could be distinguished from Caminibacter profundus by a lower optimum $\mathrm{pH}$, the inability to use oxygen as an electron acceptor, a slightly longer generation time, and susceptibility to the antibiotic chloramphenicol (Table 1). Furthermore, DNADNA hybridization of strain $\mathrm{TB}-2^{\mathrm{T}}$ and Caminibacter profundus, both of which were isolated from a vent site on the Mid-Atlantic Ridge, showed a relatedness of $35.7 \%$, indicating that the two organisms were not related at the species level (Wayne et al., 1987). Both physiological and genetic analyses indicated that $\mathrm{TB}-2^{\mathrm{T}}$ represents a novel species within the genus Caminibacter, for which we propose the name Caminibacter mediatlanticus.

Respiratory nitrate ammonification is an energy-conserving pathway, widespread among mesophilic prokaryotes (e.g. Escherichia coli, Wolinella succinogenes, Sulfurospirillum deleyianum, Desulfovibrio desulfuricans; reviewed by Potter et al., 2001; Simon, 2002), in which nitrate is reduced to 


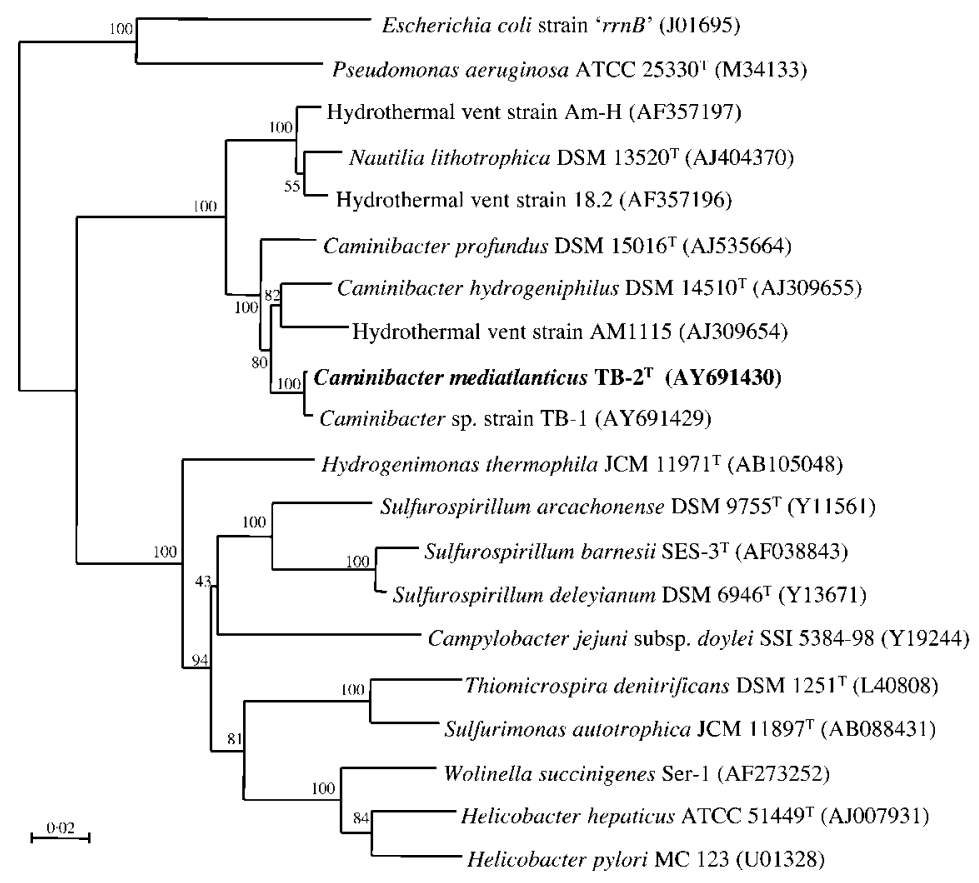

Fig. 3. Phylogenetic position of Caminibacter mediatlanticus sp. nov. TB- $2^{\top}$ based on $16 \mathrm{~S}$ rRNA gene sequences. The neighbour-joining tree was constructed using Phylo_Win. Bar, $2 \%$ estimated base substitutions. nitrite, which is subsequently reduced to ammonium. Therefore, compared with denitrification, nitrate ammonification represents a 'short cut' in the biological nitrogen cycle. Because of the primary importance of geothermally produced sulfur species at deep-sea hydrothermal vents, historically, elemental sulfur has been used as the primary electron acceptor in experimental strategies used for the isolation of thermophilic organisms (Baross \& Deming, 1995). In contrast, nitrate is depleted in hydrothermal fluids (but available in sea water) and its role as a terminal electron acceptor in anaerobic respiration of thermophilic organisms has been established in more detail only recently (R. Huber et al., 1996; H. Huber et al., 2002; Blochl et al.,

Table 1. Differentiating features of Caminibacter hydrogeniphilus, Caminibacter profundus and Caminibacter mediatlanticus sp. nov. TB- $2^{\top}$

Taxa: 1, Caminibacter hydrogeniphilus; 2, Caminibacter profundus; 3, Caminibacter mediatlanticus $\mathrm{TB}-2^{\mathrm{T}}$.

\begin{tabular}{|lccc|}
\hline Feature & $\mathbf{1}$ & $\mathbf{2}$ & $\mathbf{3}$ \\
\hline Optimal growth parameters & & & \\
Temperature $\left({ }^{\circ} \mathrm{C}\right)$ & 60 & 55 & 55 \\
$\mathrm{pH}$ & $5 \cdot 5-6 \cdot 0$ & $6 \cdot 9-7 \cdot 1$ & $5 \cdot 5$ \\
Salinity $\left(\mathrm{g}^{-1}\right)$ & $20-25$ & 30 & 30 \\
Microaerobic growth & - & Max., $2 \% ;$ & - \\
& & opt., $0 \cdot 5 \%$ & \\
Chloramphenicol resistance & - & + & - \\
DNA G+C content (mol\%) & $29 \pm 1$ & $32 \cdot 1$ & $25 \cdot 6$ \\
Generation time (min) & 90 & 40 & 50 \\
\hline
\end{tabular}

${ }^{*}$ Values given are oxygen concentrations (v/v); opt. optimum.
1997; Alain et al., 2002b, 2003; Miroshnichenko et al., 2003, 2004; Vetriani et al., 2004). These studies revealed that, along with sulfur reduction, the lithotrophic reduction of nitrate to ammonium is a bioenergetic pathway found in several thermophiles, including the hyperthermophilic archaeon Pyrolobus fumarii (Blochl et al., 1997) and several, phylogenetically diverse, thermophilic bacteria. These bacteria include Thermovibrio ruber, Thermovibrio ammonificans, 'Desulfurobacterium crinifex' (class Aquificae) (Huber et al., 2002; Alain et al., 2003; Vetriani et al., 2004), Caminibacter hydrogeniphilus, Caminibacter profundus and Caminibacter mediatlanticus (class 'Epsilonproteobacteria') (Alain et al., 2002b; Miroshnichenko et al., 2004), Caldithrix abyssi (novel bacterial lineage) (Miroshnichenko et al., 2003) and Ammonifex degensii (class 'Clostridia') (Huber et al., 1996). Most of these thermophilic, nitrateammonifying organisms are also capable of autotrophic carbon dioxide fixation. In view of the widespread distribution, importance and physiological characteristics of thermophilic e-proteobacteria in deep-sea geothermal environments, it is likely that these organisms provide a relevant contribution to both primary productivity and the biogeochemical cycling of carbon, nitrogen and sulfur at hydrothermal vents.

\section{Description of Caminibacter mediatlanticus sp. nov.}

Caminibacter mediatlanticus (me.di.at.lan'ti.cus. L. adj. medius middle; L. adj. atlanticus Atlantic; N.L. masc. adj. mediatlanticus middle Atlantic).

Cells are Gram-negative rods approximately $1.5 \mu \mathrm{m}$ in length and $0.75 \mu \mathrm{m}$ in width. Growth occurs between 45 and $70{ }^{\circ} \mathrm{C}, 10$ and $40 \mathrm{~g} \mathrm{NaCl} \mathrm{l}^{-1}$ and $\mathrm{pH} 4 \cdot 5$ and $7 \cdot 5$. 
Optimal growth conditions are $55^{\circ} \mathrm{C}, 30 \mathrm{~g} \mathrm{NaCl} \mathrm{l}^{-1}$ and $\mathrm{pH} 5.5$ (generation time $50 \mathrm{~min}$ ). Growth occurs under strictly anaerobic, chemolithotrophic conditions in the presence of $\mathrm{H}_{2}$ and $\mathrm{CO}_{2}$ with nitrate or sulfur as electron acceptors and the formation of ammonia or hydrogen sulfide, respectively. The following are not utilized as electron acceptors: oxygen, selenate, arsenate, thiosulfate and sulfite. Acetate, lactate, formate and peptone inhibit growth. No chemoorganoheterotrophic growth occurs on tryptone, Casamino acids, yeast extract $\left(0 \cdot 1 \mathrm{~g} \mathrm{l}^{-1}\right)$, sucrose or glucose. Sensitive to chloramphenicol, ampicillin and streptomycin, but resistant to kanamycin (each at $100 \mathrm{mg}$ $\left.\mathrm{ml}^{-1}\right)$. Genomic DNA G $+\mathrm{C}$ content is $25 \cdot 6 \mathrm{~mol} \%$.

The type strain is TB- $2^{\mathrm{T}}\left(=\mathrm{DSM} 16658^{\mathrm{T}}=\mathrm{JCM} 12641^{\mathrm{T}}\right)$, which was isolated from the walls of an active deep-sea hydrothermal vent on the Mid-Atlantic Ridge at $36^{\circ} 14^{\prime} \mathrm{N}$ $33^{\circ} 54^{\prime} \mathrm{W}$.

\section{Acknowledgements}

We wish to thank Cindy Van Dover for kindly providing dive time and assistance with the collection of samples and Max Häggblom for stimulating discussions. We thank Jasmine Ashraf, Susan Ellor, Kimberly Kendra, Ruth Dorn, Ronald Lauck, Priya Narasingarao and Peter Schumann for excellent technical assistance. We wish to thank the crew of R/V Atlantis and the crew and pilots of the deepsubmergence vehicle Alvin for their skilled operations at sea. This work was supported by the New Jersey Agricultural and Experiment Station (C.V.), a Research Council grant from Rutgers University (C.V.), NSF grant OCE 03-27353 (C.V.), an H. Boyd Woodruff Fellowship in Microbiology at Rutgers University (J.W.V.) and an NIH PhD Training Program in Biotechnology fellowship (J. W. V.).

\section{References}

Alain, K., Olagnon, M., Desbruyeres, D., Page, A., Barbier, G., Juniper, S. K., Querellou, J. \& Cambon-Bonavita, M. A. (2002a). Phylogenetic characterization of the bacterial assemblage associated with mucous secretions of the hydrothermal vent polychaete Paralvinella palmiformis. FEMS Microbiol Ecol 42, 463-476.

Alain, K., Querellou, J., Lesongeur, F., Pignet, P., Crassous, P., Raguenes, G., Cueff, V. \& Cambon-Bonavita, M. A. (2002b). Caminibacter hydrogeniphilus gen. nov., sp. nov., a novel thermophilic, hydrogen-oxidizing bacterium isolated from an East-Pacific Rise hydrothermal vent. Int J Syst Evol Microbiol 52, 1317-1323.

Alain, K., Rolland, S., Crassous, P. \& 9 other authors (2003). Desulfurobacterium crinifex sp. nov., a novel thermophilic, pinkishstreamer forming, chemolithoautotrophic bacterium isolated from a Juan de Fuca Ridge hydrothermal vent and amendment of the genus Desulfurobacterium. Extremophiles 7, 361-370.

Alain, K., Zbinden, M., Le Bris, N., Lesongeur, F., Querellou, J., Gaill, F. \& Cambon-Bonavita, M. A. (2004). Early steps in microbial colonization processes at deep-sea hydrothermal vents. Environ Microbiol 6, 227-241.

Baross, J. A. \& Deming, J. W. (1995). Growth at high temperature: isolation and taxonomy, physiology and ecology. In The Microbiology of Deep-Sea Hydrothermal Vents, pp. 169-217. Edited by D. M. Karl. Boca Raton, FL: CRC Press.

Blochl, E., Rachel, R., Burggraf, S., Hafenbradl, D., Jannasch, H. W. \& Stetter, K. O. (1997). Pyrolobus fumarii, gen. and sp. nov., represents a novel group of archaea, extending the upper temperature limit for life to 113 degrees C. Extremophiles 1, 14-21.

Campbell, B. J., Jeanthon, C., Kostka, J. E., Luther, G. W., III \& Cary, S. C. (2001). Growth and phylogenetic properties of novel bacteria belonging to the epsilon subdivision of the Proteobacteria enriched from Alvinella pompejana and deep-sea hydrothermal vents. Appl Environ Microbiol 67, 4566-4572.

Cary, S. C., Cottrell, M. T., Stein, J. L., Camacho, F. \& Desbruyères, D. (1997). Molecular identification and localization of filamentous symbiotic bacteria associated with the hydrothermal vent annelid Alvinella pompejana. Appl Environ Microbiol 63, 1124-1130.

Corre, E., Reysenbach, A. L. \& Prieur, D. (2001). $\varepsilon$-Proteobacterial diversity from a deep-sea hydrothermal vent on the Mid-Atlantic Ridge. FEMS Microbiol Lett 205, 329-335.

De Soete, G. (1983). A least squares algorithm for fitting additive trees to proximity data. Psychometrika 48, 621-626.

Diamond, D. (1993a). Ammonia in brackish or seawater. In QuikChem Automated Ion Analyzer Methods Manual, method 31107-06-1-A. Milwaukee, WI: Lachat Instruments.

Diamond, D. (1993b). Nitrate in brackish or seawater. In QuikChem Automated Ion Analyzer Methods Manual, method 31-107-04-1-A. Milwaukee, WI: Lachat Instruments.

Galtier, N., Gouy, M. \& Gautier, C. (1996). SEAVIEW and PHYLO_WIN: two graphic tools for sequence alignment and molecular phylogeny. Comput Appl Biosci 12, 543-548.

Haddad, A., Camacho, F., Durand, P. \& Cary, S. C. (1995). Phylogenetic characterization of the epibiotic bacteria associated with the hydrothermal vent polychaete Alvinella pompejana. Appl Environ Microbiol 61, 1679-1687.

Hoek, J., Banta, A., Hubler, F. \& Reysenbach, A. (2003). Microbial diversity of a sulphide spire located in the Edmond deep-sea hydrothermal vent field on the Central Indian Ridge. Geobiology 1, 119-127.

Huber, R., Rossnagel, P., Woese, C. R., Rachel, R., Langworthy, T. A. \& Stetter, K. O. (1996). Formation of ammonium from nitrate during chemolithoautotrophic growth of the extremely thermophilic bacterium Ammonifex degensii gen. nov. sp. nov. Syst Appl Microbiol 19, 40-49.

Huber, H., Diller, S., Horn, C. \& Rachel, R. (2002). Thermovibrio ruber gen. nov., sp. nov., an extremely thermophilic, chemolithoautotrophic, nitrate-reducing bacterium that forms a deep branch within the phylum Aquificae. Int J Syst Evol Microbiol 52, 1859-1865.

Huber, J. A., Butterfield, D. A. \& Baross, J. A. (2003). Bacterial diversity in a subseafloor habitat following a deep-sea volcanic eruption. FEMS Microbiol Ecol 43, 393-409.

Inagaki, F., Takai, K., Kobayashi, H., Nealson, K. H. \& Horikoshi, K. (2003). Sulfurimonas autotrophica gen. nov., sp. nov., a novel sulfuroxidizing $\varepsilon$-proteobacterium isolated from hydrothermal sediments in the Mid-Okinawa Trough. Int J Syst Evol Microbiol 53, 1801-1805.

Inagaki, F., Takai, K., Nealson, K. H. \& Horikoshi, K. (2004). Sulfurovum lithotrophicum gen. nov., sp. nov., a novel sulfuroxidizing chemolithoautotroph within the E-Proteobacteria isolated from Okinawa Trough hydrothermal sediments. Int J Syst Evol Microbiol 54, 1477-1482.

Kersters, K., De Vos, P., Gillis, M., Swings, J., Vandamme, P. \& Stackebrandt, E. (2003). Introduction to the Proteobacteria. In The Prokaryotes: an Evolving Electronic Resource for the Microbiological Community, 3rd edn, release 3.12. Edited by M. Dworkin. New York: Springer. http://link.springer-ny.com/link/service/books/10125/

Kodama, Y. \& Watanabe, K. (2004). Sulfuricurvum kujiense gen. nov., sp. nov., a facultatively anaerobic, chemolithoautotrophic, sulfuroxidizing bacterium isolated from underground crude-oil storage cavity. Int J Syst Evol Microbiol 54, 2297-2300. 
Longnecker, K. \& Reysenbach, A. (2001). Expansion of the geographic distribution of a novel lineage of $\varepsilon$-Proteobacteria to a hydrothermal vent site on the Southern East Pacific Rise. FEMS Microbiol Ecol 35, 287-293.

López-García, P., Duperron, S., Philippot, P., Foriel, J., Susini, J. \& Moreira, D. (2003). Bacterial diversity in hydrothermal sediment and epsilonproteobacterial dominance in experimental microcolonizers at the Mid-Atlantic Ridge. Environ Microbiol 5, 961-976.

Miroshnichenko, M. L., Kostrikina, N. A., L'Haridon, S., Jeanthon, C., Hippe, H., Stackebrandt, E. \& Bonch-Osmolovskaya, E. A. (2002). Nautilia lithotrophica gen. nov., sp. nov., a thermophilic sulfurreducing $\varepsilon$-proteobacterium isolated from a deep-sea hydrothermal vent. Int J Syst Evol Microbiol 52, 1299-1304.

Miroshnichenko, M. L., Kostrikina, N. A., Chernyh, N. A., Pimenov, N. V., Tourova, T. P., Antipov, A. N., Spring, S., Stackebrandt, E. \& Bonch-Osmolovskaya, E. A. (2003). Caldithrix abyssi gen. nov., sp. nov., a nitrate-reducing, thermophilic, anaerobic bacterium isolated from a Mid-Atlantic Ridge hydrothermal vent, represents a novel bacterial lineage. Int J Syst Evol Microbiol 53, 323-329.

Miroshnichenko, M. L., L'Haridon, S., Schumann, P., Spring, S., Bonch-Osmolovskaya, E. A., Jeanthon, C. \& Stackebrandt, E. (2004). Caminibacter profundus sp. nov., a novel thermophile of Nautiliales ord. nov. within the class 'Epsilonproteobacteria', isolated from a deep-sea hydrothermal vent. Int J Syst Evol Microbiol 54, 41-45.

Perrière, G. \& Gouy, M. (1996). WWW-query: an on-line retrieval system for biological sequence banks. Biochimie 78, 364-369.

Polz, M. F. \& Cavanaugh, C. M. (1995). Dominance of one bacterial phylotype at a Mid-Atlantic Ridge hydrothermal vent site. Proc Natl Acad Sci U S A 92, 7232-7236.

Potter, L., Angove, H., Richardson, D. \& Cole, J. (2001). Nitrate reduction in the periplasm of gram-negative bacteria. Adv Microb Physiol 45, 51-112.

Reysenbach, A. L., Longnecker, K. \& Kirshtein, J. (2000). Novel bacterial and archaeal lineages from an in situ growth chamber deployed at a Mid-Atlantic Ridge hydrothermal vent. Appl Environ Microbiol 66, 3798-3806.

Simon, J. (2002). Enzymology and bioenergetics of respiratory nitrite ammonification. FEMS Microbiol Rev 26, 285-309.

Stetter, K. O., König, H. \& Stackebrandt, E. (1983). Pyrodictium, a new genus of submarine disc-shaped sulfur reducing archaebacteria growing optimally at $105^{\circ} \mathrm{C}$. Syst Appl Microbiol 4, 535-551.

Takai, K., Inagaki, F., Nakagawa, S., Hirayama, H., Nunoura, T., Sako, Y., Nealson, K. H. \& Horikoshi, K. (2003). Isolation and phylogenetic diversity of members of previously uncultivated $\varepsilon$-Proteobacteria in deep-sea hydrothermal fields. FEMS Microbiol Lett 218, 167-174.

Takai, K., Nealson, K. H. \& Horikoshi, K. (2004). Hydrogenimonas thermophila gen. nov., sp. nov., a novel thermophilic, hydrogenoxidizing chemolithoautotroph within the E-Proteobacteria, isolated from a black smoker in a Central Indian Ridge hydrothermal field. Int J Syst Evol Microbiol 54, 25-32.

Thompson, J. D., Gibson, T. J., Plewniak, F., Jeanmougin, F. \& Higgins, D. G. (1997). The CLUSTAL_X windows interface: flexible strategies for multiple sequence alignment aided by quality analysis tools. Nucleic Acids Res 25, 4876-4882.

Vetriani, C., Jannasch, H. W., MacGregor, B. J., Stahl, D. A. \& Reysenbach, A. L. (1999). Population structure and phylogenetic characterization of marine benthic archaea in deep-sea sediments. Appl Environ Microbiol 65, 4375-4384.

Vetriani, C., Speck, M. D., Ellor, S. V., Lutz, R. A. \& Starovoytov, V. (2004). Thermovibrio ammonificans sp. nov., a thermophilic, chemolithotrophic, nitrate-ammonifying bacterium from deep-sea hydrothermal vents. Int J Syst Evol Microbiol 54, 175-181.

Wayne, L. G., Brenner, D. J., Colwell, R. R. \& 9 other authors (1987). International Committee on Systematic Bacteriology. Report of the ad hoc committee on reconciliation of approaches to bacterial systematics. Int J Syst Bacteriol 37, 463-464. 